\title{
Orang Lom: Masalah Sosial dan Ancaman Kearifan Lokal Dalam Tinjauan Sosiologi
}

\author{
Jamilah Cholillah ${ }^{1}$
}

\begin{abstract}
Social issues and local wisdom of Orang Lom People in Air Abik a contrasting duality. On the one side local knowledge continue to be maintained and preserved even exploited for the benefit of generations, but on the other side, the local wisdom, leaving only sadness being trapped on social issues such as local institutional stagnation and conflict prolonged tenure. The contrasting sides led to the existence of indigenous communities Lom People weakened and started moving towards industrialization resulted in waning social memory and the passage of the process of social exclusion.

Keyword: Social issues, conflict, exclusion, the existence
\end{abstract}

\section{A. Pendahuluan}

Bergulirnya era desentralisasi sebagai buah manis reformasi, pada kenyataannya, tidak membuat kepala daerah tergerak untuk memoles warisan budaya yang beraneka ragam menjadi sebuah peluang. Padahal, di era desentralisasi merupakan momentum besar untuk menciptakan arus perubahan sosial dan budaya seperti mempertahankan kearifan lokal komunitas adat yang sejak dulu menggadaikan dirinya demi kepentingan kelestarian lingkungan dari tradisi masyarakat urban.

Kearifan lokal merupakan konsep yang mencakup pandangan hidup, ilmu pengetahuan dan berbagai strategi kehidupan yang berwujud aktivitas yang dilakukan oleh masyarakat lokal dalam menjawab berbagai masalah dalam pemenuhan kebutuhan mereka (Tumanggor, 2007). Dalam istilah lain, kearifan lokal sering dipadankan dengan konsep kebijakan setempat (local wisdom) atau pengetahuan setempat (local knowledge). Atas dasar menjaga dan melestarikan kearifan lokal pada masyarakat/komunitas adat, sejumlah organisasi politik (orpol) memperjuangkan pengakuan hak-hak masyarakat adat, yaitu hak memiliki nilai, ideologi, politik, sosial, budaya, ekonomi, hukum serta wilayah sendiri (Simarmata, 2010).

Di sisi lain, konsep kearifan lokal yang ada di komunitas adat dipahami berbeda oleh para pemangku kepentingan. Bagi sebagian birokrat dan akademisi, melihat budaya kehidupan komunitas adat lokal sebagai sesuatu yang terbelakang dan tertinggal (kuno), sehingga perlu strategi untuk mendorong percepatan perubahan kehidupan mereka ke arah yang lebih modern. Hal itu membuat

\footnotetext{
${ }^{1}$ Dosen di Program Studi Sosiologi FISIP Universitas Bangka Belitung
} 
pemangku kepentingan cenderung bernegosiasi dengan pihak lain yang dianggap mitra strategis untuk mengembangkan sumber daya yang dimiliki oleh komunitas adat demi mengejar pendapatan asli daerah (PAD). Perbedaan pandangan tentang konsep masyarakat adat dan kearifan lokal cenderung melahirkan konflik tenurial (Arizona, 2010).

Konflik tenurial berlangsung akibat pemerintah dan pengusaha melakukan klaim atas wilayah kehidupan masyarakat adat yang sudah lama mendiami wilayahnya. Sebagian masyarakat adat terusir dari wilayahnya dan sebagian lainnya bertahan dan terus berkonflik. Fenomena konflik tenurial itu terjadi di komunitas adat 'Orang Lom' di kabupaten Bangka, Provinsi Kepulauan Bangka Belitung. Menurut Olaf $H$. Smedel dalam paper anthrobase.com yang mengatakan, bahwa komunitas "Orang Lom" di Mapur dan Air Abik sejak dulu telah memiliki wilayah pemerintahan dan politik, ekonomi, sosial dan budaya yang diatur sedemikian rupa oleh tokoh adat. Praktis, komunitas Orang Lom pun menghendaki pengakuan atas hak-haknya secara komprehensif.

Tuntutan atas pengakuan hak komunitas Orang Lom tidak berasal dari ruang hampa. Ia muncul dari dua hal yang saling terkait, yaitu faktor sejarah dan kondisi saat ini. Sejarah Orang Lom adalah sejarah budaya yang dicirikan oleh adat istiadat dan sistem kepercayaan masyarakat yang unik dan terus terpelihara lintas generasi. Hasil kajian Balitbang kabupaten Bangka tahun 2006 menguatkan, bahwa beberapa ritual dan peringatan-peringatan di komunitas Orang Lom seperti ritual pernikahan dan perceraian, kelahiran bayi, prosesi kematian, dan peringatan nujuh jerami, yaitu sedekah kampung pascapanen padi, dapat menjadi aset budaya yang patut dibanggakan dalam meningkatkan modal ekonomi daerah serta modal sosial masyarakat.

Namun faktor sejarah itu tidak linier dengan faktor kedua, yakni permasalahan multidimensional yang dihadapi komunitas Orang Lom saat ini. Dalam bidang ekonomi, pembukaan lahan hutan untuk perkebunan sawit dan tambang inkonvensional (TI) oleh perusahaan dan sebagian masyarakat di sekitar hutan Kawasan Adat Terpencil (KAT) menjadikan Orang Lom kesulitan dalam mengakses kebutuhan hidup sehari-hari, lantaran kerusakan lingkungan yang menyempitkan kawasan hutan sebagai tempat bermukim dan sumber pencaharian utama yakni menanam padi (beume). Persoalan ini tentu berimplikasi terhadap sosial budaya, yakni kian terlepasnya akar sejarah Orang Lom dari kenyataan sosiologis di mana mereka bertahan hidup dari mengandalkan alam, dan kenyataan budaya di mana mulai tergerusnya tradisi masyarakat dari budaya beume ke menambang timah inkonvensional (TI).

Kondisi yang terjadi di masyarakat adat Orang Lom tersebut menunjukkan terjadinya proses transisi tajam dalam dinamika struktur sosial, budaya, dan ekonomi di tingkat lokal di tengah arus otonomi daerah yang kian melesat. Dalam konteks kekinian, kondisi komunitas Orang Lom yang mengalami perubahan multidimensional merupakan sebuah realitas yang perlu dikaji dan ditangani secara kolektif melalui pemberdayaan komunitas berbasis pemetaan masalah sosial dan potensi kearifan lokal.

\section{B. Rumusan Masalah}

Pengelolaan dan pemanfaatan sumber daya alam yang terdapat di kawasan hutan KAT selama ini telah mengabaikan aspirasi komunitas "Orang Lom" dan 
kelestarian lingkungan untuk generasi mendatang. Rumusan masalah yang ingin diuraikan lebih lanjut adalah: (1) Apa yang menjadi masalah sosial yang sedang dialami oleh komunitas adat Orang Lom di Dusun Air Abik? (2) Bagaimana dampak masalah sosial yang dihadapi dengan keberlangsungan potensi kearifan lokal yang menjadi keunikan komunitas?

\section{Metode Penelitian}

\section{Metode Penelitian}

Penelitian ini menggunakan metode kualitatif dengan pemetaan sosial (social mapping) dan pendekatan partisipatoris (pemberdayaan partisipatif). Pemetaan sosial adalah salah satu teknik untuk memahami suatu masyarakat atau komunitas dengan memetakan permasalahan sosial yang sedang dialami, kesadaran sosial, modal sosial, persepsi, pola hidup, kebutuhan manusia, dan kondisi suku bangsa (ritual, adat istiadat). Pemetaan sosial diarahkan untuk menggali kebutuhan yang ada dalam masyarakat/komunitas sebelum memutuskan program apa yang cocok dan pantas dilaksanakan dalam suatu masyarakat (Rudito dan Famiola, 2008).

Pendekatan partisipatoris diarahkan untuk mengidentifikasi masalah kehidupan sosial yang dihadapi masyarakat menurut perspektif komunitas untuk kemudian merumuskan solusi bersama komunitas itu sendiri. Dengan kata lain, pendekatan partisipatoris berupaya untuk memantik kesadaran dan keinginan suatu komunitas untuk memahami permasalahan yang dihadapi, kemudian mencari jalan keluar untuk mencapai perubahan kehidupan. Orientasi perubahan kesadaran (mainstream) secara alamiah yang diiringi oleh tindakan kongkrit untuk mencapai perubahan (pembangunan) dalam sebuah komunitas atau masyarakat merupakan esensi dari pendekatan partisipatoris (Fernandes dan Tandon, 1993).

\section{Lokasi Penelitian}

Penelitian ini menjadikan komunitas adat Orang Lom di dusun Air Abik Desa Gunung Muda Kecamatan Belinyu Kabupaten Bangka sebagai objek kajian. Komunitas adat Orang Lom dijadikan sebagai objek setelah berdasarkan beberapa pertimbangan: pertama, terdapat tetua adat yang masih berkomitmen menjadikan nilai-nilai budaya/adat sebagai pedoman dan mendorong bagi perilaku manusia di dusun tersebut. Kedua, suku tersebut mulai mengalami perubahan sosial dalam memegang kemurnian tradisi di tengah perubahan zaman. Ketiga, komunitas adat Orang Lom masih menggunakan hukum-hukum adat dalam menyelesaikan masalah kemasyarakatan dan melestarikan tatanan sosial seperti adat pernikahan dan kematian. Keempat, komunitas adat Orang Lom memiliki hutan KAT yang menyimpan sumber daya hutan yang masih alami dan berharga.

\section{Teknik Pengumpulan Data}

Adapun teknik pengumpulan data yang digunakan dalam penelitian ini menitikberatkan pada pengamatan terlibat (participant observation), wawancara mendalam (depth interview), dan dokumentasi. Pengamatan difokuskan pada motivasi, sikap, perilaku, tindakan serta makna di balik simbol-simbol yang dapat diamati dari setiap individu ataupun kelompok (Abdullah, 2007). Wawancara mendalam mencoba mengeksplorasi secara lebih dalam persepsi-persepsi, 
pandangan serta pengalaman-pengalaman individu maupun kolektif terhadap fenomena yang sedang dan telah terjadi. Sedangkan dokumentasi dijadikan alat pendukung bagi validitas data dan informasi.

\section{Teknik Analisis Data}

Data penelitian yang telah terkumpul dianalisis secara kualitatif deskriptif. Metode ini sesuai dengan langkah-langkah yang disampaikan oleh Matthew B. Miles dan A. Michael Huberman (dalam Basrowi dan Suwandi, 2008) sebagai berikut: pertama, analisis data dilakukan dari pengumpulan informasi melalui wawancara, kuisioner maupun observasi langsung. Kedua, melakukan reduksi data yakni memilih informasi mana yang sesuai dan tidak sesuai dengan permasalahan penelitian. Ketiga, data yang telah direduksi dilanjutkan ke tahap penyajian baik berupa tabel maupun narasi. Keempat, tahap terakhir menarik kesimpulan final. Dari langkah-langkah tersebut terlihat bahwa analisis data dilakukan dalam suatu proses yang terjadi secara terus-menerus sejak pengumpulan data, reduksi data, penyajian data sampai penarikan kesimpulan.

\section{Hasil Penelitian dan Pembahasan}

Hasil penelitian diawali dengan bahasan tentang pemahaman konseptual tentang masyarakat adat, gambaran masyarakat adat Suku Lom, pemetaan masalah sosial yang dialami masyarakat adat serta analisa kelestarian kearifan lokal masyarakat adat Orang Lom di Dusun Air Abik Desa Gunung Muda Kecamatan Belinyu Bangka.

\section{Pemahaman Tentang Masyarakat Adat}

Istilah masyarakat adat mempunyai banyak pengertian yang dipahami berbeda-beda oleh kebanyakan lembaga maupun masyarakat. Guna memberi panduan dalam memahami masyarakat adat, penelitian ini memaparkan 3 (tiga) konsep pemahaman tentang masyarakat adat yang dapat dirujuk dalam memahami istilah masyarakat adat, yaitu menurut pemerintah, Lembaga Swadaya Masyarakat (LSM) dalam Kongres Aliansi Masyarakat Adat Nusantara (AMAN), dan Bank Dunia.

Menurut pemerintah, masyarakat adat lebih dikenal dengan sebutan Komunitas Adat Terpencil (KAT), yaitu "Komunitas Adat Terpencil yang selama ini dikenal dengan sebutan masyarakat terasing adalah kelompok sosial budaya yang bersifat lokal dan terpencar serta kurang atau belum terlibat dalam jaringan dan pelayanan baik sosial, ekonomi maupun politik”. Karakteristik KAT berdasarkan Pasal 1 ayat (2) Keppres No. 111 Tahun 1999 tentang Pembinaan Kesejahteraan Sosial Komunitas Adat Terpencil adalah :

a. Berbentuk komunitas kecil, tertutup dan homogen

b. Pranata sosial bertumpu pada hubungan kekerabatan

c. Pada umumnya terpencil secara geografis dan relatif sulit dijangkau

d. Pada umumnya hidup dengan ekonomi subsisten

e. Peralatan dan teknologinya sederhana

f. Ketergantungan kepada lingkungan hidup dan sumber daya alam setempat relatif tinggi 
g. Terbatasnya akses pelayanan sosial, ekonomi dan politik.

Menurut Kongres AMAN masyarakat adat adalah "komunitas-komunitas yang hidup berdasarkan asal-usul secara turun-temurun di atas satu wilayah adat, yang memiliki kedaulatan atas tanah dan kekayaan alam, kehidupan sosial budaya yang diatur oleh hukum adat, dan lembaga adat yang mengelola keberlangsungan kehidupan masyarakat" (Pandangan Dasar dari Kongres I Masyarakat Adat Nusantara 5 - 22 Maret dikutip dari Studi ANDAS EIRTP-2 Kabupaten Alor, NTT, tanpa tahun). Sementara itu AMAN memberikan batasan karakteristik masyarakat adat sebagai berikut :

a. Ketergantungan manusia dengan alam

b. Hak penguasaan dan/atau kepemilikan bersama komunitas (communal property resources) atau kolektif yang dikenal sebagai wilayah adat

c. Sistem dan struktur pengaturan berdasarkan kelembagaan adat memberikan kemampuan untuk memecahkan masalah-masalah yang mereka hadapi.

d. Sistem alokasi dan penegakan hukum adat untuk mengamankan sumberdaya milik bersama dari penggunaan berlebihan, baik oleh masyarakat sendiri maupun oleh orang luar komunitas.

e. Mekanisme pemerataan distribusi hasil panen sumberdaya alam milik bersama.

Bank Dunia menyebut Komunitas Adat Terpencil (KAT) dengan istilah Indigenous Vulnerable People (IVP) yang didefinisikan ....kelompok-kelompok yang memiliki identitas sosial dan budaya yang berbeda dari kelompok dominan dalam masyarakat dan menyebabkan mereka rentan dirugikan dalam proses penanganan. ... ( Panduan Operasional Bank Dunia OP 4.10, September 1991 tentang Masyarakat Adat yang dikutip dari Studi ANDAS EIRTP-2 Kabupaten Alor, NTT, tanpa tahun). Berdasarkan pengertian itu, Bank Dunia menekankan pada 2 (dua) hal utama yang menunjukkan komunitas adat, yaitu memiliki identitas sosial budaya berbeda (unique) dibanding kelompok dominan masyarakat dan cenderung berada dalam posisi dirugikan. Menurut Bank Dunia dalam Panduan Operasional Bank Dunia OP 4.10, September 1991, dan Draft Panduan Operasional OP 4.10, Maret 2001, tentang Masyarakat Adat, karakteristik yang diberikan bahwa kelompok masyarakat dikatakan komunitas adat (indigenous) adalah sebagai berikut :

a. Keterikatan yang kuat atas tanah leluhur dan pada sumber daya alam di area tersebut.

b. Mengidentifikasi diri sendiri dan diidentifikasi oleh lainnya sebagai kelompok yang berbeda budaya.

c. Memiliki bahasa asli yang berbeda dari bahasa nasional

d. Adanya lembaga adat sosial dan politik

e. Produksi terutama untuk kebutuhan sendiri (subsisten)

Dari ketiga pengertian tentang masyarakat adat, peneliti menitikberatkan pada istilah masyarakat adat menurut AMAN dan Bank Dunia, karena secara substansi keduanya cenderung melihat masyarakat adat dari unsur keunikan yang dimiliki termasuk kearifan lokal dan adanya upaya mempertahankan eksistensi 
serta menyelamatkan identitas kultural dari ancaman eksploitasi sistem dari luar melalui kelembagaan adat.

\section{Gambaran Komunitas Adat Orang Lom}

Orang Lom adalah komunitas yang tinggal di wilayah yang tersebar di tiga dusun, yaitu Dusun Air Abik, Dusun Pejem, dan Dusun Tuing. Berdasarkan data wawancara dengan Kepala Dusun Air Abik, persebaran warga komunitas di Air Abik saat ini adalah yang terbesar dibanding dua dusun lainnya. Dusun Air Abik memiliki batas-batas sebelah selatan berbatasan dengan Desa Silip, sebelah utara berbatasan dengan Dusun Pejem, sebelah timur berbatasan dengan Desa Silip, dan sebelah barat berbatasan dengan Desa Gunung Muda. Secara geografis Dusun Air Abik terletak antara $01^{\circ} 37^{\prime} 0.01^{\prime \prime}$ LS $105^{\circ} 54^{\prime} 47.9$ "BT dengan luas wilayah sekitar 6000 hektar (ha). Jarak dari Sungailiat sebagai ibukota kabupaten menuju Dusun Air Abik sekitar $\pm 101 \mathrm{~km}$.

Dari sisi sejarah, keberadaan Orang Lom di Belinyu masih simpang-siur. Berdasarkan penuturan dari tetua adat Orang Lom, Orang Lom pertama kali mendiami Air Abik yang terletak di hulu Sungai Mapur. Terdapat dua versi sejarah keberadaan Suku Lom. Versi pertama mengatakan bahwa "suku Lom merupakan keturunan dari bangsawan Majapahit di Mojokerto, Jawa Timur, yang lari karena tidak mau memeluk Islam, sekitar abad ke-16 M. Kaum pelarian itu menyeberangi laut untuk mencari penghidupan baru dan terdampar di Tanjung Tuing" (Kompas, 2005). Versi kedua, "suku Lom berasal dari komunitas Vietnam yang mendarat dan menetap di daerah Gunung Muda, Belinyu, sekitar abad ke-5 M. Jadi, suku itu telah ada jauh sebelum Kerajaan Sriwijaya yang berkembang abad ke-7 Masehi dan kuli kontrak timah dari China berdatangan sekitar abad ke18 M" (Kompas, 2005).

Sebagian besar komunitas Orang Lom masih memeluk kepercayaan asli yang disebut politeisme, yaitu kepercayaan terhadap adanya roh-roh ghaib. Dengan kepercayaan ini membuat mereka masih mempercayai mitos dan mistis. Mitos yang sampai saat ini masih dipercayai oleh warga komunitas adalah mitos Bubung Tujuh. Bubung Tujuh yang berarti tujuh rumah tertua di komunitas Lom merupakan rumah yang ditempati oleh keturunan pertama dari nenek moyang setelah kedua orang tua mereka meninggal. Rumah yang didirikan oleh ketujuh saudara itu berbentuk rumah panggung yang tinggi, berdinding kulit kayu dan beratap daun nipah.

Dari sisi mistis, adanya penghormatan terhadap benda fisik sebagai makhluk yang memiliki jiwa (fetisisme) yang kemudian mempengaruhi pengetahuan dan sendi kehidupan, membuat mereka mengkultuskan benda-benda seperti pohonpohon, batu, dan hewan. Kepercayaan inilah yang membuat mereka disebut "Orang Lom" atau orang yang belum beragama.

Seperangkat kepercayaan itu dijaga oleh lembaga adat yang diketuai oleh ketua adat. Ketua adat harus berasal dari keturunan asli Orang Lom yang dianggap paling disegani dan paling senior. Tugas seorang ketua adat adalah memimpin setiap pelaksanaan ritual adat seperti upacara kelahiran dan kematian, tradisi perkawinan, dan pesta adat Nujuh Jerami.

Secara kelembagaan, lembaga adat Suku Lom di Air Abik memiliki tugas menjaga dan memelihara tradisi dan keyakinan leluhur yang masih asli terutama pada aspek bertanam padi ladang (beume), menjaga kelestarian hutan adat dan 
sungai. Usaha menjaga tradisi itu terlihat dari adanya seperangkat aturan dan larangan (pantangan) seperti tidak boleh masuk ke arena pemakaman Orang Lom bagi orang luar sebelum meminta izin kepada tetua adat, mengambil kayu di hutan adat dengan cara menebang, bersiul di malam hari, membunuh binatang di malam hari, menjemur pakaian di pagar rumah, mengangkat jemuran di sore hari, membunyikan suara atau alat musik di waktu senja (maghrib), dan pantanganpantangan lainnya. Pelanggaran terhadap aturan atau pantangan itu akan dikenakan sanksi adat yang bersifat sanski moral atau psikis seperti mendapat murka dari alam, musibah, menderita sakit aneh, dan kemasukan roh halus.

Sejarah keberadaan Orang Lom di Air Abik beserta sistem kepercayaan, nilai-nilai, dan sistem kelembagaan yang ada dapat dikategorikan sebagai masyarakat adat dan hal ini sesuai dengan definisi dari AMAN, yaitu suatu komunitas yang memiliki asal-usul leluhur yang secara turun temurun hidup di wilayah geografis tertentu, serta memiliki sistem nilai, ideologi, ekonomi, politik, budaya dan sosial yang khas. Hal ini diperkuat oleh pandangan Olaf H. Smedel dalam paper anthrobase.com yang mengatakan, bahwa komunitas "Orang Lom" di Mapur dan Air Abik sejak dulu telah memiliki wilayah pemerintahan dan politik, ekonomi, sosial dan budaya yang diatur sedemikian rupa oleh tokoh adat.

\section{Masalah Sosial Masyarakat Adat Suku Lom}

Berdasarkan hasil identifikasi lapangan terdapat masalah-masalah sosial yang sedang dialami oleh komunitas adat Orang Lom di Dusun Air Abik. Masalah-masalah sosial dibagi pada dua permasalahan, yaitu masalah internal dan eksternal. Masalah internal meliputi kemandegan pranata sosial, sistem keyakinan dalam hal perkawinan (keturunan), dan identitas yang terancam. Masalah eksternal lebih difokuskan pada konflik tenurial yang telah berlangsung sejak satu dekade terakhir.

Lembaga adat memiliki tugas menjaga dan memelihara tradisi serta keyakinan leluhur yang masih asli. Dengan demikian, lembaga adat yang terdapat di Dusun Air Abik berperan sebagai institusi lokal yang mempunyai kuasa tersendiri dalam mengatur tata kehidupan masyarakatnya. Konsep kekuasaan itu dimaknai sebagai bentuk adanya kontrol sosial terhadap norma, nilai, dan aturan yang masih dijalankan dalam kehidupan masyarakat adat. Kontrol sosial itu masih berjalan secara parsial. Sebab disatu sisi ketua adat masih berperan dalam mengatur ritual-ritual adat seperti perkawinan, kelahiran, kematian, upacara adat "Nujuh Jerami" serta bertanggung jawab menyelesaikan permasalahanpermasalahan yang ada dalam masyarakat adat Suku Lom. Tetapi disisi lain, ketua adat tidak dapat berperan dalam menjaga kelestarian seni dan hutan adat oleh ekspansi perkebunan kelapa sawit milik perusahaan PT Gunung Pelawan Lestari (GPL).

Peran lembaga adat yang mengalami kejumudan dalam memecahkan persoalan yang dihadapi oleh masyarakat adat terutama regenerasi keturunan dan pengelolaan hutan adat berdampak pada terjadinya perubahan pola pikir dan orientasi pada masyarakat adat Suku Lom. Beberapa indikator perubahan itu dapat dilihat dari: Pertama, lembaga adat tidak dapat mempertahankan kehidupan tradisional yang diwarisi oleh leluhur akibat masyarakat adatnya telah beradaptasi dengan kehidupan modern, sehingga pemberlakuan aturan adat tidak 
menimbulkan dampak moral atau psikis bagi warga adat. Ini terlihat dari sebagian pantangan yang bersumber dari lembaga adat seperti tidak boleh menebang kayu dan menambang timah di hutan adat. Kenyataannya saat ini, sebagian warga adat Lom melakukan kedua aktivitas tersebut di hutan adat demi meningkatkan pendapatan.

Kedua, hubungan antara lembaga adat dan lembaga Dusun di Air Abik yang pada awalnya saling bersinergi dan saling terkait dalam masalah adat mulai mengalami kelonggaran. Lembaga dusun yang diwakili oleh Kepala Dusun cenderung mendominasi dalam setiap pengambilan keputusan menyangkut penyelenggaraan ritual adat seperti pesta adat Nujuh Jerami dan pengelolaan hutan KAT. Sebagian hutan adat dan hutan rakyat yang terdapat di Air Abik oleh Kepala Dusun dapat diakses oleh warga adat dan warga lain untuk membuka tambang inkonvensional (TI) di mana dusun akan mendapat kompensasi berupa uang dari hasil TI tersebut berdasarkan jumlah kilogram timah yang didapat oleh petambang. Hal ini dapat berdampak pada perubahan orientasi material yang selalu mengejar uang tanpa harus menjaga keseimbangan alam yang selama ini diwarisi oleh leluhur.

Ketiga, Orang Lom mengalami keterancaman identitas akibat sebagian warga adatnya sudah beragama, baik Islam maupun Kristen, meskipun sebatas simbolik, sebatas tertera dalam Kartu Tanda Penduduk (KTP) tetapi tidak menjalankan ibadah seperti tuntunan agama yang telah dianut. Identitas yang mulai terancam lebih disebabkan oleh pola geneologi (keturunan), intensitas perkawinan, kematian, dan kebijakan (Zulkarnain, 2009). Dalam tradisi Orang Lom adalah hal yang lumrah terjadi jika orang tua yang masih "Lom" (belum memeluk salah satu agama resmi negara) menjadi orang "Lah" (memeluk salah satu agama) ketika terdapat anak yang sudah memeluk agama. Misalnya, ada orang tua yang masih "Lom" dan anak-anaknya banyak yang memeluk agama Islam, secara otomatis orang tua biasanya mengikuti agama sang anak dengan menjadi seorang Muslim. Pilihan menjadi orang "Lah" bukan tanpa alasan mendasar. Ada semacam kekhawatiran pada diri orang tua yang masih "Lom" jika tidak menjadi orang "Lah" yang terkait dengan hak mengurus jenazah (kematian) mereka kelak. Dengan kata lain, orang tua yang meninggal dalam keadaan masih "Lom" tidak boleh jenazahnya disentuh oleh anak-anaknya yang sudah menjadi orang "Lah". Ketakutan itu membuat orang tua termotivasi untuk menjadi orang "Lah". Tetapi, ada hal unik terkait pola keturunan dalam komunitas adat Orang Lom. Meskipun orang tua mengikuti agama sang anak, tidak serta merta keluarga tersebut menjadi orang "Lah" seluruhnya. Di antara anggota keluarga tersebut harus ada salah satu yang masih menjadi orang "Lom" untuk kepentingan regenerasi keturunan.

Dalam hal perkawinan, kaum perempuan memiliki stratafikasi sosial yang lebih tinggi dibanding kaum laki-laki. Ketika perempuan dewasa maupun muda yang telah menikah dengan laki-laki dari Orang Lom berkeinginan untuk menjadi orang "Lah", maka laki-laki Orang Lom biasanya mengikuti agama yang dipeluk oleh sang istri. Sebagai contoh, sang istri yang semula beragama Kristen maka sang suami pun ikut menjadi Kristen. Tradisi ini secara tidak langsung dapat mengancam eksistensi komunitas adat Orang Lom. Selain itu, faktor kematian turut mengancam eksistensi tersebut. 
Keempat, konflik agraria dan ancaman kelestarian sumber daya alam. Penelitian lapangan melalui pemetaan potensi sumber daya kearifan lokal komunitas Lom di Dusun Air Abik pada kenyataannya mengalami ambiguitas. Sebab, pada saat penelitian dilakukan dalam upaya mengajak dan menghimpun warga komunitas adat untuk mulai mengidentifikasi potensi yang tersimpan di hutan adat (hutan primer) dan hutan sekunder demi kepentingan pemberdayaan, namun disisi lain, fakta di lapangan peneliti dihadapkan dengan nuansa sengketa lahan antara perusahaan perkebunan kelapa sawit dengan warga komunitas Orang Lom di Dusun Air Abik di kawasan hutan adat. Artinya, potensi kearifan yang ada di kawasan hutan adat dalam situasi terancam dan sangat mengkhawatirkan bagi keberlangsungan dan kelestarian kearifan local di masa mendatang.

\section{Masa Depan Orang Lom}

Masalah-masalah sosial yang sedang dihadapi Orang Lom tidak linier dengan potensi budaya yang dimiliki sejak turun-temurun. Potensi budaya meliputi: budaya beume (berladang), pengetahuan tradisional tentang tumbuhan obat, pengetahuan tradisional tentang hutan, dan mitos peninggalan bersejarah Orang Lom.

\section{a. Tradisi beume}

Kebiasaan Orang Lom yang masih bertahan hingga sekarang adalah budaya subsisten dengan pola pertanian ladang berpindah. Pola ladang berpindah dengan bertanam komoditas berupa padi (beras merah) yang biasa disebut beume dan lada, membuat Orang Lom leluasa memanfaatkan hutan. Pertanian padi dengan pola ladang berpindah merupakan salah satu peninggalan kebudayaan nenek moyang yang mengandung filosofi menjaga dan melestarikan lingkungan. Tradisi beume yang melahirkan produk beras merah hampir dilakukan oleh setiap komunitas adat. Sepanjang kawasan hutan adat sekunder, dapat ditemukan ladangladang padi (huma) dengan mudah.

Kebiasaan Orang Lom pada periode antara menabur benih dengan cara "nugel", yaitu melobangi tanah untuk menanam benih dengan menggunakan kayu dan panen padi (ngetem) biasa disebut dengan periode menunggu padi. Pada saat ini, Orang Lom di Air Abik melakukan berbagai aktivitas produktif seperti mencari rotan dan daun nipah untuk bahan baku anyaman, berburu, dan memancing di sungai. Jika masa panen padi tiba, seluruh kerabat dan tetangga ikut serta dalam aktivitas memanen padi. Hasil panen biasanya dipakai untuk konsumsi sehari-hari, tidak untuk dijual. Kegiatan puncak masa panen padi beras merah adalah diselenggarakannya sedekah kampung yang biasa disebut nuju jerami.

b. Pengetahuan tradisional tentang tumbuhan obat

Pengetahuan Orang Lom tentang tumbuhan obat dapat dilacak melalui persepsi mereka yang memandang bahwa semua tumbuhan yang mengandung rasa pahit mempunyai khasiat sebagai obat. Persepsi itu didukung oleh ketersediaan bahan obat-obatan di alam sekitar terutama di semak belukar, hutan, dan sekitar sungai tempat bermukim warga komunitas pedalaman. Hal inilah yang membuat warga komunitas bersikukuh bahwa semua tumbuhan tersebut harus tetap dijaga dan dilindungi demi kelangsungan kelestariannya. 
Menurut penelitian Nova Adelia (Adelia, 2010), komunitas Orang Lom membedakan jenis tanaman kayu yang satu dengan yang lainnya berdasarkan ciriciri morfologis seperti warna kulit kayu, bentuk dan ukuran daun, kekerasan kayu, dan ciri-ciri sensorial (bau dan rasa yang beraneka ragam). Sedangkan perbedaan jenis tumbuhan berdasarkan batang, daun, tangkai daun, tangkai bunga, tangkai buah, dahan/ranting, akar, bunga, biji, dan buah.

Berdasarkan kajian lapangan tahap awal dapat diketahui jenis keanekaragaman tumbuhan obat yang biasa dimanfaatkan oleh warga komunitas Lom yang diolah sesuai dengan kebudayaannya. Proses pengolahan berbagai jenis tumbuhan itu melalui cara ditumbuk, diminum, dan dioles. Menurut keterangan Sukri, Ketua Adat Komunitas Lom di Dusun Air Abik, terdapat beberapa jenis penyakit dan cara pengobatan yang hingga saat ini masih dilestarikan oleh warga komunitasnya. Beberapa penyakit dan cara pengobatannya dapat dideskripsikan berikut ini:

\section{Mengobati luka}

Luka yang dialami oleh warga komunitas akibat tersayat pisau, parang, tertimpa pohon/kayu, mengalami kecelakaan dan lain sebagainya biasanya diobati dengan menggunakan daun kemunting, atau ditempat lain biasa disebut keramunting. Daun kemunting yang banyak terdapat di semak belukar di sekitar hutan diambil pucuknya lalu ditumbuk atau bisa dikunyah agar bisa halus, setelah daun dirasa halus bagian yang terkena luka ditempelkan dan dibiarkan selama beberapa hari sampai luka tersebut mengering.

\section{Penawar racun binatang liar}

Tempat bermukim warga komunitas khususnya di pedalaman hutan yang umumnya rumah dengan berdinding kulit kayu atau papan dan berlantai tanah, serta kebiasaan warga komunitas pedalaman yang berjalan kemana-mana tanpa menggunakan alas kaki, memungkinkan untuk dihinggapi dan digigit oleh binatang liar seperti ular dan lipan. Orang Lom memiliki keunikan tersendiri untuk mengobati penyakit yang disebabkan oleh pengaruh racun akibat digigit ular atau lipan. Sebagai contoh, gigitan lipan biasa diobati dengan menggunakan daun simpur bini. Daun tersebut ditumbuk hingga halus lalu ditempelkan pada bagian tubuh yang digigit lipan. Pelan-pelan rasa nyeri dan ngilu di bekas gigitan dan sekitarnya akan reda.

\section{Sakit demam}

Panas di sekujur tubuh yang melebihi kondisi normal dapat diobati dengan akar tumbuhan mentupuk dan daun mesunur. Akar mentupuk dicuci dengan air hingga bersih lalu akar ditumbuk sampai pipih dan memar. Setelah itu akar direndam dalam air lalu disaring. Air yang telah disaring diminum untuk menurunkan panas. Daun mesunur yang masih banyak terdapat di hutan Dusun Air Abik dipetik sebanyak 7 (tujuh) lembar dicuci dengan air hingga bersih, lalu direbus dengan tiga gelas air hingga mendidih. Air dididihkan hingga tersisa satu gelas untuk diminum.

\section{Sakit mata}


Bagi warga komunitas yang terkena sakit mata yang dicirikan dengan mata merah dan mengeluarkan cairan atau kotoran, biasa diobati dengan tumbuhan ketuyut. Tumbuhan ketuyut adalah jenis tumbuhan yang seringkali tumbuh di sekitar aliran sungai atau biasa disebut warga dengan lelap. Ketuyut dalam istilah bahasa Indonesia disebut kantung semar di mana kantung semar dapat menampung air. Air yang ada dalam ketuyut biasanya diteteskan ke dalam mata yang terserang sakit atau dapat juga diminum secara langsung.

c. Pengetahuan tradisional tentang hutan

Orang Lom pedalaman (meskipun sangat tertutup dan sulit diakses) sangat mensakralkan hutan. Keterangan Hamid, seorang warga Desa Gunung Muda, yang pernah tinggal dan bertemu dengan Orang Lom pedalaman memperkuat hal tersebut. Orang Lom yang bermukim di dalam hutan Benak hidup berpencarpencar dan hanya sedikit yang berdekatan (berkelompok). Bagi Orang Lom pedalaman, hutan dan tanah adalah nafas kehidupan. Hutan merupakan lingkungan alam yang paling dilindungi, sehingga dianggap sebagai kawasan primer. Hal tersebut diperkuat oleh Nova Adelia (Adelia, 2010) dengan mengklasifikasi hutan komunitas Lom menjadi dua, yaitu hutan adat (hutan lindung) dan hutan terlarang. Kedua klasifikasi hutan itu tidak boleh dirusak dan dieksploitasi meskipun atas nama pembangunan. Berdasarkan informasi dari Hamid, hutan adat di Dusun Air Abik menyimpan banyak potensi sumber daya alam dan kearifan yang eksotik. Hutan adat masih sangat alami dan jarang diakses oleh para pendatang dari dalam maupun dari luar Dusun Air Abik. Sebab akses jalan menuju hutan adat pedalaman tidak dilengkapi dengan sarana jalan yang memadai. Akses menuju kawasan hutan adat pedalaman di Benak dapat dilewati dengan menyusuri tiga batang kayu yang sengaja dibaringkan di atas aliran sungai, sehingga menyulitkan bagi pengendara sepeda motor. Kendaraan roda empat tidak dapat melewati jalan tersebut.

Hutan adat pedalaman menyimpan banyak sumber daya alam seperti kayu, tumbuhan obat-obatan, akar kayu, rotan, aneka satwa langka (pelanduk, tarsius,) dan berbagai jenis burung lainnya. Dari jenis kayu, masih banyak terdapat kayu gaharu, meranti, dan nyatoh. Selain hutan adat, terdapat juga hutan sekunder yang oleh warga komunitas adat seringkali dijadikan sebagai lokasi menanam padi ladang (beras merah), lada, dan karet. Berdasarkan hasil identifikasi lapangan, masih banyak terdapat kayu dan madu pelawan, rotan untuk alat sunatan dan bahan baku keruntong (wadah anyaman dari rotan untuk keperluan berladang), dan daun bengkuang untuk bahan anyaman tikar dan kiding (wadah menampung padi waktu panen).

d. Peninggalan sejarah Orang Lom

Komunitas Orang Lom memiliki beberapa peninggalan sejarah berupa situs yang hingga saat ini jarang diketahui oleh masyarakat luas di Pulau Bangka. Menurut keterangan sesepuh adat Orang Lom, Sa'ban, bukti sejarah tersebut merupakan peninggalan Ki Antak yang dipercayai mempunyai nilai mistis yang tinggi.

Sumber kajian lapangan yang dilakukan oleh tim Sosiologi Universitas Bangka Belitung tahun 2009, bukti sejarah itu tersimpan di sebuah lokasi antara pertengahan Dusun Tuing dan Dusun Pejem yang berupa batu gendang, batu 
saba', para Aki, dan telapak kaki Ki Antak. Batu gendang tersebut dipercayai milik leluhur Orang Lom Ki Antak dan gendang itu biasa digunakan untuk menghibur diri. Konon mitos yang dipercayai, jika gendang itu ditabuh, maka air laut akan pasang secara tiba-tiba.

Batu saba' adalah batu yang sebentuk ular besar yang konon bersumber dari cerita Ki Antak yang sedang berburu dengan membawa seekor anjing. Pada saat berburu, anjing Ki Antak dililit seekor ular besar, biasa disebut Saba'. Melihat hal itu, Ki Antak pun membunuh ular tersebut dengan cara memotong-motong tubuhnya menjadi beberapa bagian. Potongan ular itu lama kelamaan menjadi batu menyerupai jalan setapak.

Para Aki merupakan tempat panggangan makanan leluhur Orang Lom, biasanya dipakai untuk memanggang hasil tangkapan yang diperoleh dari hasil berburu binatang terutama babi hutan dan rusa. Telapak kaki Ki Antak dianggap bukti bersejarah yang sering dianggap mitos oleh sebagian masyarakat Pulau Bangka. Konon, telapak kaki itu berukuran sangat besar. Pada saat pengkajian lapangan di lokasi situs-situs bersejarah berlangsung, tim tidak menemukan bekas telapak kaki tersebut.

Kenyataan yang dihadapi komunitas adat Orang Lom terbenam di antara masalah-masalah sosial terutama konflik tenurial yang berkelanjutan dan menutupi potensi-potensi kearifan lokal yang sejak lama eksis, sehingga memunculkan dilema masyarakat industri yang berdampak meredupkan potensipotensi dan keunikan yang menyejarah sekalipun. Dilema masyarakat industri menurut Herbert Marcus (Saeng, 2012), disebabkan oleh peranan ilmu pengetahuan dan teknologi. Dengan ilmu pengetahuan manusia diarahkan untuk dapat menguasai pikiran dan kesadarannya, dengan itu terciptalah rasionalitas. Seiring perkembangan zaman, rasionalitas selalu berjalan dan berkembang linier dengan pesatnya ilmu pengetahuan, yang pada akhirnya terbentuklah rasionalitas teknologi. Karakteristiknya, segala sesuatu yang dianggap penting dan berharga, harus dikuasai, digunakan, dan dimanipulasi. Subjek utamanya adalah manusia, karena manusia memiliki kehendak untuk menciptakan, memanipulasi dan memperalat benda-benda termasuk alam sebagai sarana mempermudah kehidupannya. Lantaran manusia sebagai subjek, maka karakteristik menguasai dan memanipulasi berlangsung juga di ranah politik dan kultural. Di sinilah manusia dan masyarakat selalu berada dalam penguasaan dan manipulasi teknologi.

Dampak bagi komunitas adat Orang Lom terhadap proses jalannya relasi antara ilmu pengetahuan dan teknologi, seharusnya membawa ke arah tingkat kemakmuran yang patut dibanggakan. Gemerlap kemakmuran, kesenangan, dan kenyamanan hidup dirasakan sejak kehadiran PT GPL yang keberadaannya didukung oleh Pemda. Pada kenyataannya, dibalik gemerlap kemakmuran yang hanya dinikmati segelintir orang/kelompok tertentu, harus dibayar dengan pemiskinan dan peminggiran warga komunitas melalui pembatasan akses atas wilayah hutan dan sumber daya alam (eksklusi). Praktek eksklusi sosial ini meniadakan aspek keamanan, kenyamanan, dan ketentraman hidup yang selama ini menjadi pembentuk sosio kultural komunitas adat Orang Lom serta relasinya dengan lingkungan hidup. Praktik eksklusi yang disertai dengan pengekangan dan penindasan melalui seperangkat adminitrasi total yang merupakan "strategi pengaturan dan pengelolaan yang bertujuan mengharmoniskan pemusatan dan 
penyatuan kekuatan sosial, politik, ekonomi, militer dan budaya ke dalam satu tangan", telah "memaksa semua warga agar memerlukan yang tidak diperlukan dan mengorbankan yang harus dilindungi dan dilestarikan" (Saeng, 2012). Dalam konteks ini, Orang Lom mulai melupakan ingatan sosial yang telah melekat pada diri setiap warga komunitasnya secara perlahan-lahan. Pada akhirnya, Orang Lom hanya tinggal nama yang terukir dalam coretan tinta sejarah.

\section{E. Penutup}

Penelitian menghasilkan dua hal penting, yaitu: pertama, masalah-masalah sosial yang dihadapi komunitas adat Orang Lom di Dusun Air Abik mengarah pada disfungsional pranata sosial kelembagaan adat dan konflik tenurial yang dapat mengancam eksistensi komunitas dan keberlanjutan potensi kearifan lokal. Kedua, dampak sosial yang akan dihadapi oleh komunitas adat Orang Lom akibat pertautan antara ilmu pengetahuan dan teknologi yang dijalankan oleh perusahaan perkebunan kelapa sawit mengarah pada tergerusnya ingatan sosial yang berujung pada praktik eksklusi sosial, menempatkan komunitas adat Orang Lom sebagai "orang asing" di tanah ulayatnya sendiri. 


\section{DAFTAR PUSTAKA}

Abdullah, Irwan, 2007, Pengantar Metode Penelitian Kualitatif, Yogyakarta: Handout Pascasarjana UGM.

Adelia, Nova. 2010. Pengetahuan Tradisional Tentang Pemanfaatan Tumbuhan Obat Oleh Masyarakat Suku Lom Di Dusun Air Abik Gunung Muda Kecamatan Belinyu-Bangka. Sungailiat: Laporan Penelitian Skripsi.

Arizona, Yance.2010. Satu Dekade Legislasi Masyarakat Adat: Trend legislasi nasional tentang keberadaan dan hak-hak masyarakat adat atas sumber daya alam di Indonesia (1999-2009) dalam Kertas Kerja Epistema no. 07/2010, hal. 1 .

Bank Dunia OP 4.10, September 199, Panduan Operasional tentang Masyarakat Adat yang dikutip dari Studi ANDAS EIRTP-2 Kabupaten Alor, NTT, tanpa tahun (diakses September 2015)

Bangka Pos, Jangan Jual Hutan Adat Kami, Jumat, 13 Januari 2012, hal. 5.

Basrowi dan Suwandi, 2008, Memahami Penelitian Kualitatif. Jakarta: PT Rineka Cipta.

Fernandes, Walter dan Tandon, Rajesh, 1993, Riset Partisipatoris Riset Pembebasan, Jakarta: Gramedia Pustaka Utama.

Rudito, Bambang, dan Famiola, Melia. 2008, Social Mapping Metode Pemetaan Sosial. Bandung: Rekayasa Sains.

Saeng CP, Valentinus, 2012. Herbert Marcuse Perang Semesta Melawan Kapitalisme Global. Jakarta: Gramedia Pustaka Utama.

Simarmata, 2010, Adat Dalam Politik Indonesia. Jakarta: Yayasan Pustaka Obor Indonesia dan KITLV-Jakarta.

Smedel, Olaf H. Order and Difference An Ethnographic Study of Orang Lom of Bangka, West Indonesia. Originally published in the series Oslo Occasional Papers in Social Anthropology, as Occasional Paper No.19 Department of Social Anthropology, University of Oslo, 1989. Dikutip dalam Anthrobase.com (diakses 12 Oktober 2015).

Tumanggor, Rusmin. Pemberdayaan Kearifan Lokal Memacu Kesetaraan Komunitas Adat Terpencil dalam Jurnal Penelitian dan Pengembangan Kesejahteraan Sosial Volume 12, No. 01 Januari-April 2007, hal. 1-17.

Zulkarnain, Iskandar. Selamatkan Orang Lom (1) dalam harian Babel Pos, 22 Januari 2010, hal. 5 
, Selamatkan Orang Lom (2) dalam harian Babel Pos, 23 Januari 2010, hal. 5 